\title{
Effects of 'Active Participation and Organization' in a Nature Conservation Project: Study of a Teaching Technique
}

\author{
Dr. Armin Baur \\ University of Education Schwäbisch Gmünd \\ Oberbettringer Straße 200, D-73525 Schwäbisch-Gmünd \\ Tel: 0049-717-198-3445Ｅ-mail: armin.baur@ph-gmuend.de \\ Prof. Dr. Hans-Martin Haase \\ University of Education Schwäbisch Gmünd \\ Oberbettringer Straße 200, D-73525 Schwäbisch-Gmünd \\ Tel: 0049-717-198-3297Ｅ-mail: haase@ph-gmuend.de
}

Received: September 12, 2016 Accepted: September 29, 2016

doi:10.5296/emsd.v5i2.10231ＵRL: http://dx.doi.org/10.5296/emsd.v5i2.10231

\begin{abstract}
This article presents the technique of active participation and organization in environmental protection activities, and compares it with two other similar teaching techniques. The body of the presentation recounts the investigation into the impact of the teaching technique within the behavioral area of nature conservation, specifically protection of spotted salamander. The investigation tests the hypothesis, as to whether the technique of active participation and organization in environmental protection activities to conserve nature results in a positive change in pupils' environmental behavior. The design of the examination comprised one test group and two control groups; one of the control groups receives only tuition, the second none. Data were gathered concerning the environmental perception, the self-reported willingness to act as well as the observable behavior. Positive results could be found. A positively altered willingness of the test group to act was established and their observable behavior differed after the teaching.
\end{abstract}

Keywords: Environmental education, Environmental behavior, Teaching technique, Activity-oriented tuition 


\section{Introduction}

Climate warming (Bernstein \& Pachauri, 2008), the extinction of many animal species (Hirsch, 2010), the demonstration of a hole in the ozone layer at the north pole of the same extent as that at the south pole (Manney et al., 2011), all caused by human actions. At this point these few examples should serve to substantiate the argument, that for present and future generations, the alteration of behavior towards the environment of every single person is a matter of great urgency.

Ecological sustainability is accordingly expressed by the OECD as a most important aim for the community, for which pupils should acquire the necessary competences (OECD, 2005). Sustainability involves a positive and responsible environmental behavior (cp. here Agenda 21: UNCED, 1993) and is to be regarded as an extremely important goal in education. Effective teaching techniques can contribute to achieving this goal.

\section{The Teaching Technique}

One possible technique is the "technique of active participation and organization in environmental protection activities" (subsequently referred to as "active participation and organization"). The technique is basically founded on the principal that pupils have the possibility, to employ their own ideas and skills and thereby achieve changes to improve the existing local environmental situation. This, such is the expectation, has a positive effect upon the environmental behavior of the pupils. The environmental problems broached in class are expected to have arisen out of the pupils' own locality. The important basic principle is that the alteration in environmental behavior should not arise out of manipulation by the teacher, through direct influence on the actions, but rather that the pupils have freedom to decide for themselves what (or what not) to do.

The teaching technique comprises two phases. The first phase concerns the imparting of facts and regular action knowledge for the behavioral area (e.g. in which dustbin belongs which waste, or protection of amphibians ...) and consists of pupil oriented, constructive teaching. The pupils work out the contents in groups then present and discuss them with the whole class. The teacher accompanies and provides support to the pupils as required (see appendix 4 for an example).

The first phase is considered necessary to teach knowledge. Although many studies verify that factual knowledge (knowledge about environmental problems) has no strong, proven effect (Grob, 1991; Diekmann \& Franzen, 1996) it should still be regarded as a necessary factor. Who is able to behave in a conscious and purposeful manner concerning the environment, if unaware of the existing problems? However, behavioral knowledge (knowledge about how to reduce environmental problems) has a mediating function between attitude and behavior (Schahn \& Holzer, 1990). In recognition of this, both (factual and behavioral knowledge) are taken up. Disregarding any influence(s) on behavior, the transfer of knowledge is important in the second phase, in order to deal in a worthwhile manner with the problem presented and the changes arising.

Following the first phase is the presentation of a local problem (e.g. at our school waste is not 
being sorted, or in/by the local stream many spotted salamander are dying ....), which leads to the second phase. In the second phase the pupils consider possibilities as to how they might alter the situation, work out their ideas during a project-oriented class, and carry out the resulting "protective action" (see appendix 4 for an example).

One concept that is comparable to the portrayed technique is the IIAT (Issue Investigation and Action Training). IIAT was examined by Ramsey, Hungerford and Tomera (1981), Ramsey and Hungerford (1989) and by Ramsey (1993). With IIAT pupils learn to identify environmental problems and values and are introduced to problem solving strategies, upon which they then act.

A further similar educational concept "Environmental service learning" was described in a study by Schneller (2008). The concept for the course includes normal instruction concerning environmental problems and subsequently carries out projects in which pupils themselves actively participate (hands on projects). The environmental themes were regional: e.g. clearing and cleaning of a beach, study of local plants and taking part in campaigns to protect turtles.

The difference between the method of "active participation and organization" and the constituted methods is that pupils have the possibility to collaborate in the design and organization of the environmental projects (this is seen as the central component of the technique). The pupils were not, as in IIAT, specifically taught about problem solving procedures, but rather they themselves develop their own capabilities by introducing their own ideas. The pupils do not merely, as by Schneller, take part in actions. By the technique of "active participation and organization" the pupils design and construct the actions themselves. Through doing this themselves, through success and/or failure, they acquire action competences and responsibility. The improvement in the action competence and possibility of success in protective actions offers the opportunity to reinforce the pupils' locus of control (their belief that their actions can alter situations). The knowledge, that they may themselves be partially responsible (e.g. with the problem of waste separation), can influence the pupils' attribution of responsibility. Cooperative participation encourages the development of a social/subjective norm. The pupils attempt to change the environmental behavior of their fellow citizens, acquiring a social requirement to behave as they would expect others to do.

Studies show, that the locus of control has a positive effect on one's own environmental behavior (Hines, Hungerford, \& Tomera, 1986; Bamberg \& Möser, 2007). The attribution of responsibility influences behavior little to moderately (Hines et al., 1986; Kastenholz, 1994; Menzel \& Bögeholz, 2008). The subjective norm is contained in the model of the theory of planned behavior (TPB) by Ajzen $(1985,2006)$ as one of three triggers of intention to act. The subjective norm is social pressure (behavioral expectations of important reference persons), as appreciated by the subject. In studies concerning environmental behavior the social norm is seen as having little to moderate influence (Kastenholz, 1994; Gotschi, Vogel, Lindenthal, \& Larcher, 2010).

In an earlier study concerning the behavioral area "waste separation" the use of the teaching technique of "active participation and organization" showed a significant positive change in 
the reported and observed environmental behavior of pupils (aged between 10 and 13 years) (Baur, 2013; Baur \& Haase, 2015).

Of interest here, is whether these positive results also arise in other areas of behavior. In this article the teaching technique shall be tested within the behavioral area "nature conservation".

\section{Hypothesis}

In the following the teaching technique of "active participation and organization in environmental protection activities" is to be tested in the behavioral area of "nature conservation". Subjects of the study are not the supposed effects of the instruction (phases 1 +2 ) upon the predictors of action competence, attribution of responsibility, locus of control or social norm, but rather the effect on the environmental behavior of the pupils.

$\mathrm{H}_{1}$ : The active participation and organization of pupils in environmental protection activities improves their own environmental behavior. $\left(\mathrm{H}_{1}\right.$ : $\mathrm{PEB}_{1}<\mathrm{PEB}_{2} ; \mathrm{PEB}_{1}=$ proenvironmental behavior before the trial, $\mathrm{PEB}_{2}=$ proenvironmental behavior afterwards)

$\mathrm{H}_{0}: \quad \mathrm{PEB}_{1} \geq \mathrm{PEB}_{2}$

The chosen significant test level is $5 \%$.

\section{Method of Study}

First the partial theme for the study of the behavioral area "nature conservation" must be chosen (further partial themes must follow), which offered itself for tuition and is appropriate for pupils. Chosen was an action for the protection of spotted salamanders, as there was in the area of the three schools involved a stream in which spotted salamander larvae and adults were in danger. Following the drying out of several parts of the stream in recent years, larvae were endangered and the adult animal through motor vehicles at night. The cause of the drying out is hitherto unclear. The lack of water led to the death of a large number of spotted salamander larvae through desiccation. The study was carried out among pupils of year 6 (age of the pupils between 11 and 13 years). The design of the study comprised of one test group (T-group) and two control groups (C1- and C2-group). The test group ( $\mathrm{N}=117$; male $=60$; female $=57$ ) received teaching concerning "The spotted salamander", "The development of spotted salamander larvae" and "Threats to local amphibians". Following the tuition the pupils took part in an action to relocate spotted salamander larvae (approved by the Stuttgart administrative authority), devised and created a campaign to inform their fellow citizens in the local parishes, of the threat to spotted salamander from motor vehicles driving along narrow country lanes (the treatment is shown in appendix 4). Control group $1(\mathrm{~N}=82$; male $=47$; female $=35$ ) received the same instruction as the test group, but was neither involved in the relocation action nor did it devise a campaign. Control group $2(\mathrm{~N}=111$; male $=50$; female $=61$ ) received no instruction, nor was it involved in the relocation action, nor did it devise a campaign. The groups (test, control 1 and control 2) had no significant difference in their gender relation $\left(\chi^{2}=2.87, \mathrm{p}>.05\right)$. Care was taken to include pupils from each school in each of the three groups. All three groups were questioned before (pre) and after (post) the 


\section{Ml Macrothink}

intervention using the environmental perception (environmental awareness) form from Bogner (Bogner \& Wiseman, 1999, 2002). The test group was additionally examined after the intervention using the Intrinsic Motivation Inventory (IMI) from Deci \& Ryan (without year) and an questionnaire developed for this study "Open-ended Questionnaire" (see table 1). The pupils' answers of the developed questionnaire ("Open-ended Questionnaire") were analyzed by two raters who consulted one another (see coding schemes appendix 1, 2, and 3). The qualitative content analysis of Mayring (2008) was used for the analyzing. Subsequently a further rater analyzed $25 \%$ of the data. The selection of these was with random number generator. The aim of the second analysis was to determine reliability (for results see table 1).

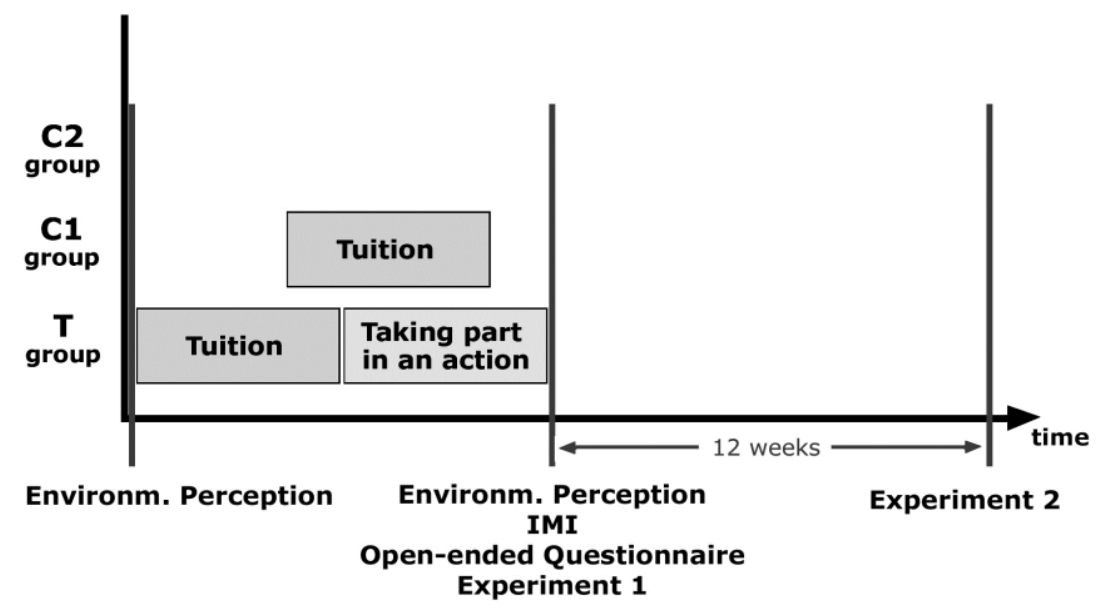

Figure 1. Planning of the study of the behavioral area "nature conservation"

Table 1. Open-ended Questionnaire

\begin{tabular}{|c|c|c|}
\hline Items & & Rater-reliability \\
\hline (1a) & $\begin{array}{l}\text { Before the action to protect the spotted salamander, did you want to do anything to } \\
\text { protect wild animals and plants? }\end{array}$ & Cohen's $\kappa=.94$ \\
\hline (1b) & $\begin{array}{l}\text { Do you now wish (after the action) to do anything to protect wild animals and } \\
\text { plants? }\end{array}$ & Cohen's $\kappa=.77$ \\
\hline (1c) & Explain why your willingness to do anything has changed / not changed. & $\mathrm{C}=.61$ \\
\hline (2a) & $\begin{array}{l}\text { Has your opinion, since the action to protect the spotted salamander, about nature } \\
\text { conservation changed? }\end{array}$ & Cohen's $\kappa=.72$ \\
\hline (2b) & Explain why your opinion has / has not changed. & $\mathrm{C}=.58$ \\
\hline
\end{tabular}

All three groups (T-, C1- and C2- group) were offered to cooperate in an action to collect old mobile phones (field experiment 1) directly after the intervention and twelve weeks after the intervention in an action to collect money (field experiment 2). The proceeds from field experiment 1 was contributed to a gorilla protection project, the donations collected in field experiment 2 passed on to protect orangutans. The participating pupils were counted and the differences between the different groups compared.

\section{Results}

After the procedure the test group showed a positive change in their willingness to act for endangered wild animals and plants (established by questions $1 \mathrm{a}$ and $1 \mathrm{~b}$ in the Open-ended 


\section{Macrothink}

Questionnaire). The alterations were certified with the Wilcoxon test and are significant $(p<.01, d=0.32$; see Table 2$)$. The effect dimension $d$ is calculated with the difference of the mean scores divided by the pooled standard deviation. Using the motivation form (IMI) a high rating from the pupils over the conservation action was determined on the chart "value/usefulness" $(\mathrm{M}=3.91, \mathrm{SD}=.87)$, "interest/enjoyment" $(\mathrm{M}=3.91, \mathrm{SD}=.86)$, "effort/importance" $(\mathrm{M}=3.72, \mathrm{SD}=.74)$, and "perceived choice" $(\mathrm{M}=3.61, \mathrm{SD}=.90)$. Documented observable behavior shown by the test- and control group 1 in field experiment 1 was more active (figure 3) than that of control group 2. Twelve weeks afterwards following the field experiment 2, no difference could be determined between the groups.

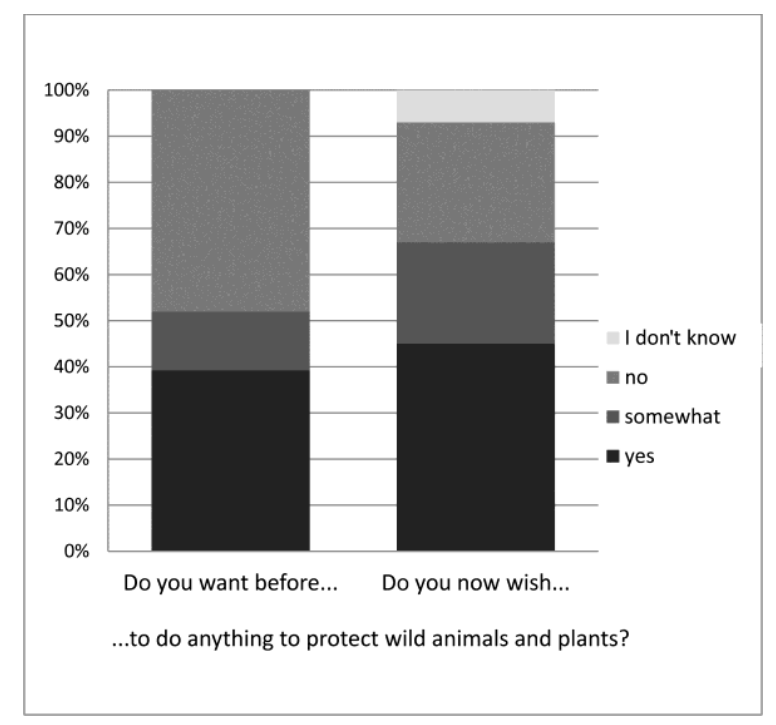

Figure 2. Reported willingness to act of the test group

$54 \%$ of the pupils (test group) showed improved attitudes to nature conservation (34\% answered question 2a with "yes", $20 \%$ with "somewhat" and $46 \%$ with "no").

The environmental perception of the test group and control groups showed no measurable positive change. No significant correlation between alteration of willingness to act and the two main charts ("preservation" and "utilization") on the environmental perception form could be measured. The alteration of willingness to act was ascertained by subtracting that before the intervention from that after.

Table 2. Change in the willingness to act of the test group

\begin{tabular}{|l|ll|}
\hline \multicolumn{3}{|c|}{ Wilcoxon test: } \\
\hline \multirow{3}{*}{ WA (after) - WA (before) } & {$[-] 11$} & 203.00 \\
Test group & {$[+] 29$} & 617.00 \\
& {$[0] 51$} \\
& {$[\mathrm{~N}] 91$} \\
& $\mathrm{Z}=-2.89$ \\
& $\mathrm{p}=.002$ (one sided) \\
& $\mathrm{d}=0.32$ \\
\hline $\begin{array}{l}\text { WA }=\text { willingness to act for endangered wild animals and plants. The values } \\
\text { beside the number of positive and negative ranks show the corresponding rank sum. }\end{array}$ \\
\hline
\end{tabular}




\section{Macrothink}
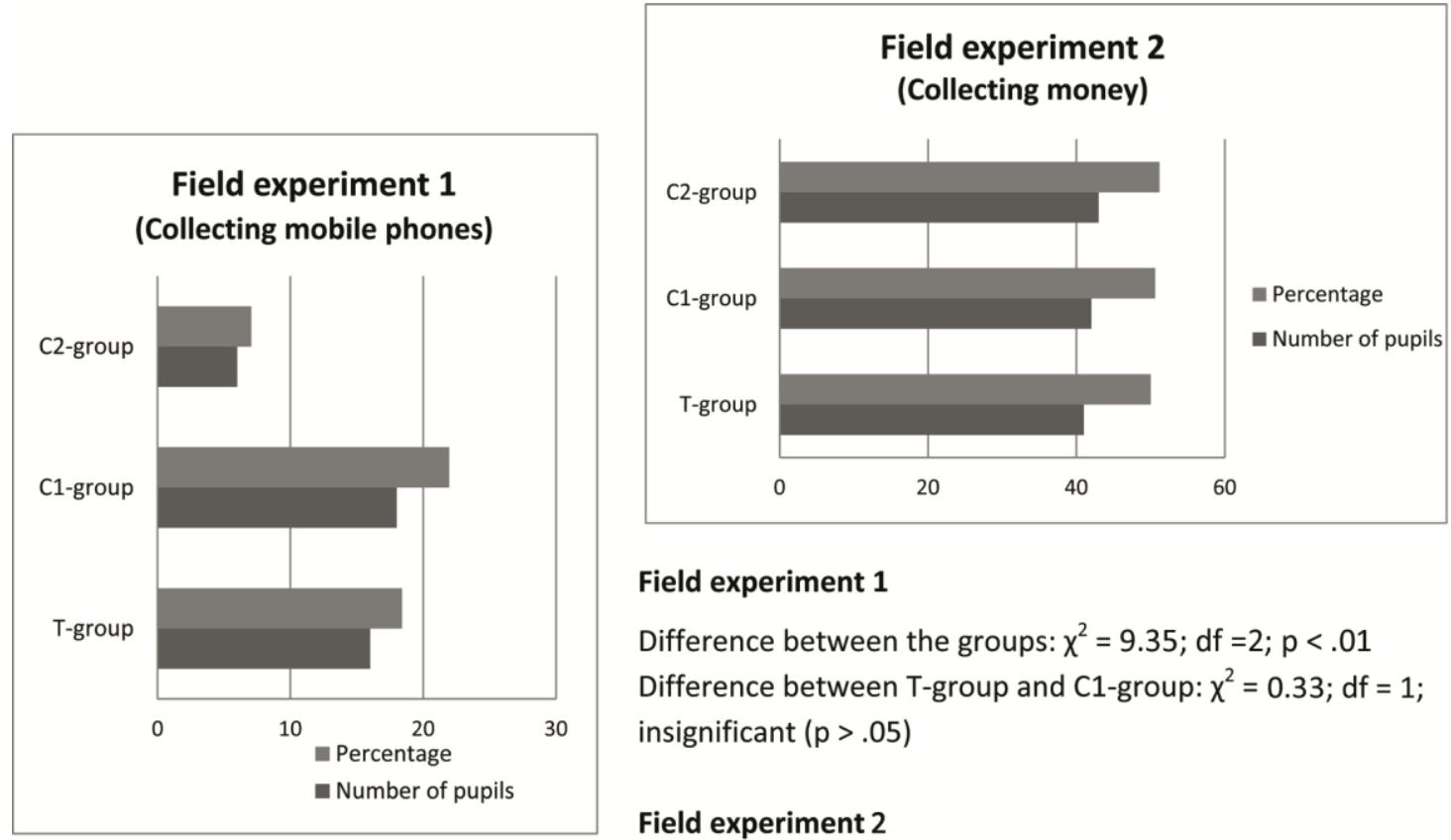

Field experiment 1

Difference between the groups: $\chi^{2}=9.35 ; \mathrm{df}=2 ; \mathrm{p}<.01$

Difference between T-group and C1-group: $\chi^{2}=0.33$; $d f=1$;

insignificant $(p>.05)$

Field experiment 2

No difference between the groups: $\chi^{2}=0.03 ; \mathrm{df}=2 ; \mathrm{p}>.05$

Figure 3. Results of the field experiments in the behavioral area "nature conservation"

The behavioral enquiry segments "intent of support" and "care with resources" in the environmental perception questionnaire showed no significant improvement in the test group, nor in the groups $\mathrm{C} 1$ and $\mathrm{C} 2$.

Furthermore, the gender of pupils showed no correlation to any alteration of willingness to act.

For the largest portion (35\%) of the pupils from the test group the reported spur for their positive alteration of willingness to act was the recognition/opinion: that the animals and plants have a right to live. $26 \%$ gave as the spur for their positive alteration in their willingness to act that it gave them pleasure to do something for the wild plants and animals. $64 \%$ of the pupils who did not alter their willingness to act, stated, that they were already willing to do something for wild plants and animals before the action. $20 \%$ wrote that they could not be bothered or weren't interested.

\section{Discussion}

During the study the test group improved its' reported willingness to act significantly, and the observable behavior after the test differed from that of group $\mathrm{C} 2$, however not from that of group $\mathrm{C} 1$, which lead to the conclusion that also the information mediating tuition (phase 1 of the treatment - which is also a part of the method) can be seen here as a trigger factor. Although the willingness to act cannot be directly equate with behavior but the intention (willingness) to act is the factor in the structure model of the meta-analysis form Bamberg \& Möser (2007) which leads to a real behavior (path-coefficient: intention to behavior $=0.52$ ). 
The hypothesis, that the "active participation and organization in environmental protection activities" improves the environmental behavior of pupils can only be confirmed by this study for a short term effect but not for a long term effect. This wasn't the case in an earlier research on the teaching technique in the behavioral area "waste separation". In this earlier study a short and a long term effect and differences between the test on C1-group in the reported and observable behavior was detected (Baur, 2013; Baur \& Haase, 2015). The difference in the long term effect between the studies suggests that the low-cost-hypothesis of Diekmann \& Preisendörfer also can be transferred to the effects of interventions (cp. Low-cost hypothesis of Diekmann \& Preisendörfer, 1992, 1998, 2003). A paraphrase for this transfer would be: Low-cost-areas are easier for intervention than high-cost-areas.

Further studies, to confirm this phenomenon are here decisive, since it is an important factor in the planning and realization of teaching. If there are points of difference here, one should keep in mind the following points:

(1) A balanced relationship between low- and high-cost areas should be a central theme, in order to act in a consistent and comprehensive manner.

(2) Interventions in high-cost-areas could require more tuition time and should eventually after a suitable time be repeated to consolidate the changes.

It must be analyzed in further investigations why in this study the phase 1 had an effect but not in the earlier study "waste separation".

In both studies (in the earlier study on the area "waste separation" and in this one) only the area of behavior which was the topic altered. The portions of the environmental perception form dealing with "intent of support" and "care with resources" indicated no recognizable change. The portion "intention to support" recorded the willingness to join a nature conservation group so as to convince others concerning environmental protection etc.. The portion "care of resources" asked about dealing with energy. Accordingly the response to the hypothesis must be, in concrete form: The teaching technique of "active participation and organization" only changes behavior of pupils in those areas specifically dealt with during tuition and action - in this study especially the protection of wild plants and animals.

The environmental perception (environmental awareness) of the test group had not altered, despite a positive change in the environmental behavior. This shows that the sole view on environmental awareness is a poor indicator for the evaluation of an intervention. Added to which is the absence of correlations of the environmental perception with the changes in behavior.

Gender had no influence on behavioral change during the intervention. This contrasts with the findings of environmental behavioral research (e.g. Diekmann \& Preisendörfer, 1992; Stern, 1993), in which an effect of gender (women's behavior more strongly altered), upon practice in environmental behavior was ascertained. The result determined in the research shows that in this behavioral area, no gender specific approach in teaching seems to be necessary. 


\section{Macrothink}

The values of the scales from the Intrinsic Motivation Inventory (IMI) make clear that the pupils consider such a form of tuition as interesting, useful, and important. This is also a necessary criterion in the pedagogical view and supports the efficiency of the teaching technique.

Further research into this teaching method is necessary in order to determine its effect in other areas of behavior.

For a good education for sustainable development in school one needs various successful teaching methods which can be used by teachers. Our research will contribute to this.

\section{Conclusion}

The implementation of the teaching technique "active participation and organization in environmental protection activities" produced - in the described study in the area nature conservation (protection of spotted salamanders) - positive effects on the environmental behavior and the willingness to act in the test group. The teaching technique led also in an earlier study - in the area waste separation (Baur, 2013; Baur \& Haase, 2015) - to changes in the observed and reported behavior with pupils from the test group. The distinction between the result from the study in the area of waste separation and the result from this study in the area of nature conservation is that in the area of waste separation the test group showed differences to the control groups in tested observed behavior even in the follow up test (long term effects). Although the results show that the teaching technique works, there are a difference in the sustainable effect, which are most probably caused by the content that is taught about through the teaching method.

\section{Acknowledgement}

The first author acknowledges the contributions of Sabine Schubert, Linda Kuhl, Alexandra Würtz, Monika Schleicher, Irmgard Hahn, Jutta Scherzinger, Ingeborg Haueissen, Carina Christ, Christine Heimann, Martina Kaufmann-Wieland, and Susanne Herweck-Brieskorn by the performance of the intervention, Sabine Müller for the assistance in the analysis of data, and Peter Tralls, Margaret Tralls, Heike Grund, and Markus Emden for the support by the translation.

\section{References}

Ajzen, I. (1985). From intentions to actions: A theory of planned behavior. In J. Kuhl (Ed.), Springer series in social psychology. Action control. From cognition to behaviour. Berlin: Springer, 11-39. http://dx.doi.org/10.1007/978-3-642-69746-3_2

Ajzen, I. (2006). TPB. [Online] Available:

http://www.people.umass.edu/aizen/tpb.diag.html\#null-link (03.09.2009)

Bamberg, S., \& Möser, G. (2007). Twenty years after Hines, Hungerford, and Tomera: A new meta-analysis of psycho-social determinants of pro-environmental behaviour. Journal of Environmental Psychology, 27(1), 14-25. http://dx.doi.org/10.1016/j.jenvp.2006.12.002

Baur, A. (2013). Verändert die aktive Beteiligung und Mitgestaltung an 
Umweltschutzaktionen das Umwelthandeln von Schülern?: Empirische Untersuchung einer Intervention zur Veränderung des Umwelthandelns. Hamburg: Dr. Kovač.

Baur, A., \& Haase, H.-M. (2015). The influence of active participation and organisation in environmental protection activities on the environmental behaviour of pupils: Study of a teaching technique. Environmental Education Research, 21(1), 92-105. http://dx.doi.org/10.1080/13504622.2013.843645

Bernstein, L., \& Pachauri, R. K. (2008). Klimaänderung 2007: Synthesebericht (IPCC). Berlin.

Bogner, F. X., \& Wiseman, M. (1999). Toward measuring adolescent environmental perception. European Psychologist, 4(3), 139-151.

http://dx.doi.org/10.1027//1016-9040.4.3.139

Bogner, F. X., \& Wiseman, M. (2002). Environmental perception: Factor profiles of extreme groups. European Psychologist, 7(3), 225-237. http://dx.doi.org/10.1027//1016-9040.7.3.225

Deci, E. L., \& Ryan, R. M. (without year). Intrinsic Motivation Inventory (IMI). [Online] Available: http://www.selfdeterminationtheory.org/questionnaires/10-questionnaires/50 (02.09.2009)

Diekmann, A., \& Franzen, A. (1996). Einsicht in ökologische Zusammenhänge und Umweltverhalten. In R. Kaufmann-Hayoz (Ed.), Umweltproblem Mensch. Humanwissenschaftliche Zugänge zu umweltverantwortlichem Handeln. Bern: Haupt, 135-157.

Diekmann, A., \& Preisendörfer, P. (1992). Persönliches Umweltverhalten: Diskrepanz zwischen Anspruch und Wirklichkeit. Kölner Zeitschrift für Soziologie und Sozialpsychologie, 44, 226-251.

Diekmann, A., \& Preisendörfer, P. (1998). Umweltbewußtsein und Umweltverhalten in Lowund High-Cost-Situationen: Eine empirische Überprüfung der Low-Cost-Hypothese. Zeitschrift für Soziologie, 27(6), 438-453. http://dx.doi.org/10.1515/zfsoz-1998-0604

Diekmann, A., \& Preisendörfer, P. (2003). Green and greenback: The behavioral effects of environmental attitudes in low-cost and high-cost situations. Rationality and Society, 15(4), 441-472. http://dx.doi.org/10.1177/1043463103154002

Gotschi, E., Vogel, S., Lindenthal, T., \& Larcher, M. (2010). The role of knowledge, social norms, and attitudes toward organic products and shopping behavior: Survey results from high school students in vienna. The Journal of Environmental Education, 41(2), 88-100. http://dx.doi.org/10.1080/00958960903295225

Grob, A. (1991). Meinung - Verhalten - Umwelt: Ein psychologisches Ursachennetz-Modell umweltgerechten Verhaltens. Bern: Lang.

Hines, J., Hungerford, H., \& Tomera, A. (1986). Analysis and synthesis of research on responsible environmental behavior: A meta-analysis. The Journal of Environmental 
Education, 18(2), 1-8. http://dx.doi.org/10.1080/00958964.1987.9943482

Hirsch, T. (2010). Global biodiversity outlook 3. Montreal, Quebec, Canada: Secretariat of the Convention on Biological Diversity.

Kastenholz, H. G. (1994). Bedingungen umweltverantwortlichen Handelns in einer Schweizer Bergregion: Eine empirische Studie unter der besonderen Berücksichtigung anthropogen verursachter Klimaveränderungen. Bern: Lang.

Manney, G. L., Santee, M. L., Rex, M., Livesey, N. J., Pitts, M. C., Veefkind, P. et al. (2011). Unprecedented Arctic ozone loss in 2011. Nature, 478(7370), 469-475.

http://dx.doi.org/10.1038/nature10556

Mayring, P. (2008). Qualitative Inhaltsanalyse: Grundlagen und Techniken (10., neu ausgestattete Aufl.). Weinheim: Beltz.

Menzel, S., \& Bögeholz, S. (2008). Was fördert eine Bereitschaft von Oberstufenschüler(inne)n, die Biodiversität zu schützen? Eine standardisierte Befragung in Anlehnung an die Value-Belief-Norm-Theorie. Umweltpsychologie, 12(2), 105-122.

OECD (2005). The definition and selection of key competencies, Executive summary. [Online] Available: http://www.oecd.org/dataoecd/47/61/35070367.pdf

Ramsey, J. M. (1993). The effects of issue investigation and action trainig on eighth-grade students' environmental behavior. The Journal of Environmental Education, 24(3), 31-36. http://dx.doi.org/10.1080/00958964.1993.9943501

Ramsey, J. M., \& Hungerford, H. R. (1989). The effects of issue investigation and action training on environmental behavior in seventh grade students. The Journal of Environmental Education, 20, 29-34. http://dx.doi.org/10.1080/00958964.1989.9943036

Ramsey, J. M., Hungerford, H. R., \& Tomera, A. N. (1981). The effects of environmental action and environmental case study instruction on the overt environmental behavior of eighth-grade students. The Journal of Environmental Education, 13, 24-29.

http://dx.doi.org/10.1080/00958964.1981.9943021

Schahn, J., \& Holzer, E. (1990). Studies of individual environmental concern: The role of knowledge, gender, and background variables. Environment and Behavior, 6(22), 767-786. http://dx.doi.org/10.1177/0013916590226003

Schneller, A. J. (2008). Environmental service learning: outcomes of innovative pedagogy in Baja California Sur, Mexico. Environmental Education Research, 14(3), 291-307. http://dx.doi.org/10.1080/13504620802192418

Stern, P. C. (1993). Value orientations, gender, and environmental concern. Environment and Behavior, 25(3), 322-348. http://dx.doi.org/10.1177/0013916593255002

United Nations Conference on Environment and Development. (1993). Agenda 21: programme of action for sustainable development. Rio Declaration on Environment and Development. Statement of Forest Principles: The final text of agreements negotiated by 
governments at the United Nations Conference on Environment and Development (UNCED), 3-14 June 1992, Rio de Janeiro, Brazil. New York: United Nations.

\section{Appendix}

Appendix 1. Coding scheme Question 1a

\begin{tabular}{|c|c|c|}
\hline \multicolumn{3}{|c|}{$\begin{array}{l}\text { Question: Before the action to protect the spotted salamander, did you want to do anything to protect wild } \\
\text { animals and plants? }\end{array}$} \\
\hline Category & Definition & Example \\
\hline Yes & $\begin{array}{l}\text { Proband states clearly that he wanted to do } \\
\text { something. }\end{array}$ & $\begin{array}{l}\text { "Yes, while it was important to me to protect the } \\
\text { environment." }\end{array}$ \\
\hline Somewhat & $\begin{array}{l}\text { Proband indicates that he only wished to } \\
\text { do a little / do something. }\end{array}$ & $\begin{array}{l}\text { "Yes, but not so much now."; "I have only done a } \\
\text { little bit / a part of something." }\end{array}$ \\
\hline No & $\begin{array}{l}\text { Proband states clearly that he wished to do } \\
\text { nothing. }\end{array}$ & "No, not really". \\
\hline
\end{tabular}

Appendix 2. Coding scheme Question 1b

\begin{tabular}{|c|c|c|}
\hline \multicolumn{3}{|c|}{ Question: Do you now wish (after the action) to do anything to protect wild animals and plants? } \\
\hline Category & Definition & Example \\
\hline Yes & $\begin{array}{l}\text { Proband states clearly that he } \\
\text { wants to do something. }\end{array}$ & "Yes, while it is important to me to protect the environment." \\
\hline Somewhat & $\begin{array}{l}\text { Proband indicates that he only } \\
\text { wishes to do a little / do } \\
\text { something. }\end{array}$ & $\begin{array}{l}\text { „Gladly, when I have more time“"; ,something“; ,Maybe a little } \\
\text { bit, for example my girlfriend wants to tear up a plant, I'll say } \\
\text { no, don't do that" }\end{array}$ \\
\hline No & $\begin{array}{l}\text { Proband states clearly that he } \\
\text { wants to do nothing. }\end{array}$ & „No because it doesn't interest me.“ \\
\hline $\begin{array}{l}\text { I don't } \\
\text { know }\end{array}$ & Proband is unsure. & „Yes, perhaps.“, „I don’t know.“ \\
\hline
\end{tabular}

\section{Appendix 3. Coding scheme Question 2a}

\begin{tabular}{|l|l|l|}
\hline $\begin{array}{l}\text { Question: Has your opinion, since the action to protect the spotted salamander, about nature conservation } \\
\text { changed? }\end{array}$ \\
\hline Category & \multicolumn{1}{|c|}{ Definition } & \multicolumn{2}{|c|}{ Example } \\
\hline Yes & Proband states clearly that he has changed his opinion. & $\begin{array}{l}\text { "Yes, because I now enjoy it and it } \\
\text { interests me." }\end{array}$ \\
\hline Somewhat & $\begin{array}{l}\text { Proband states, he has only changed his opinion a little / } \\
\text { altered a little bit. }\end{array}$ & $\begin{array}{l}\text { "Yes, a little bit."; "A little better than } \\
\text { before." }\end{array}$ \\
\hline No & Proband states clearly, that he has not altered his opinion. & "No, in fact, not!"; "Not really" \\
\hline
\end{tabular}


Appendix 4. The complete treatment of the test group

\begin{tabular}{|c|c|c|}
\hline \multirow{4}{*}{ 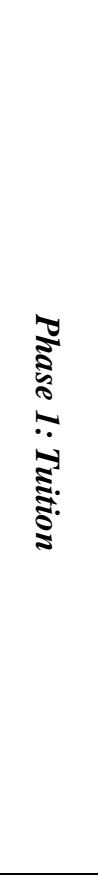 } & lesson (per 45 min.) & content of the lesson \\
\hline & The spotted salamander & $\begin{array}{l}\text { The teacher talks with the pupils about points which are } \\
\text { required in a description. } \\
\text { The pupils search information about the spotted salamander on } \\
\text { the internet and work out a description. } \\
\text { Some pupils present their descriptions. }\end{array}$ \\
\hline & $\begin{array}{l}\text { The development of spotted } \\
\text { salamander larvae }\end{array}$ & $\begin{array}{l}\text { The pupils watch a film about the development of the larvae of } \\
\text { spotted salamander. They work in groups. Each group has a } \\
\text { different order to work out one station of the development. } \\
\text { The pupils present their results. } \\
\text { All pupils write down the development on a worksheet. }\end{array}$ \\
\hline & Threats to local amphibians & $\begin{array}{l}\text { The teacher shows a diagram of the share of the population of } \\
\text { amphibians in } 1945 \text { and } 2002 \text {. The diagram pictures the } \\
\text { decrease of the German amphibians. The teacher discusses the } \\
\text { diagram with the pupils. } \\
\text { The pupils work out information about amphibian preservation } \\
\text { from a text. } \\
\text { The pupils' results will be discussed. }\end{array}$ \\
\hline 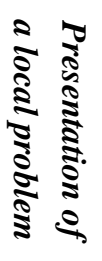 & \multicolumn{2}{|c|}{$\begin{array}{l}\text { The pupils are focused with a local problem. } \\
\text { In the described treatment the teacher and the pupils visited a local area in which spotted salamander } \\
\text { live. The pupils saw run down salamanders and endangered salamander larvae. }\end{array}$} \\
\hline 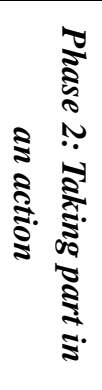 & \multicolumn{2}{|c|}{$\begin{array}{l}\text { In this phase the pupils think about what they could do to change the situation. They work out their } \\
\text { ideas, plan and perform the action. } \\
\text { In the treatment described in this article the pupils created flyers, posters, exhibitions and wrote } \\
\text { articles for the local newspaper to inform the citizens about the endangered spotted salamanders. } \\
\text { It is important in this phase that the pupils develop the ideas all by themselves. The teacher shall not } \\
\text { lead. He helps the pupils to work out their own ideas and motivates. } \\
\text { (The time which is needed can differ because of the vast variety of ideas the pupils develop - in the } \\
\text { described treatment it took eight lessons) }\end{array}$} \\
\hline
\end{tabular}

\section{Copyright Disclaimer}

Copyright for this article is retained by the author(s), with first publication rights granted to the journal.

This is an open-access article distributed under the terms and conditions of the Creative Commons Attribution license (http://creativecommons.org/licenses/by/3.0/). 